\title{
Flexural Resistance of Esthetic Materials Used by Indirect Restoration. A Comparative in vitro Study
}

\author{
Resistencia Flexural de Restauraciones Indirectas Estéticas. Estudio Comparativo in vitro
}

Ignacio Muñoz Fernandez*; Rodrigo Florio Mogollones*" \& Manuel Velásquez Castilla***

MUÑOZ, F. I.; FLORIO, M. R. \& VELÁSQUEZ, C. M. Flexural resistance of esthetic materials used by indirect restoration. A comparative in vitro study. Int. J. Odontostomat., 7(2):315-318, 2013.

ABSTRACT: The use of indirect restorations have increased in tooth with great dental destruction due to their physical and mechanical properties that bestow higher durability than other type of restoration. The aim of the study was to compare the flexural resistance of four indirect restoration materials (composite Filtek P60; ceromers Adoro and Ceramage; ceramic IPS e.max), by testing the hypothesis that ceramic has a higher flexural resistance than ceromer and composite. Ten bars of each material were made following the 27, 53, 69 ANSI/ADA norms and the manufacturer's instructions. The flexural resistance was obtained by a three-point test using the Instron machine at a loading rate of $1 \mathrm{~mm} / \mathrm{min}$. The resistance was calculated in MPa and the results were statistically analyzed through ANOVA y Scheffé tests. Filtek P60 flexural resistance is significantly higher than Ceramage. Adoro flexural resistance is significantly lower than all the other materials. It is necessary to make absolutely clear that the research was executed in vitro, whereby its resistances may differ than in mouth because of the cementation and the "mono-block" formation. Through the research it was determined that Filtek P60 is significantly higher than Ceramage, and that Adoro is significantly less than all the other compared materials regarding flexural resistance; whereby the raised hypothesis is nullified. materials.

KEY WORDS: mechanical phenomena, permanent dental restoration, composite resins, ceramics, dental

\section{INTRODUCTION}

Since the beginning of history people have been concerned with their smile aesthetics, and for this reason improvements are constantly made in biomaterials. The first restorative materials were very durable, but their aesthetic was poor, since they were grey or metallic color. Through the years aesthetics evolved and patients no longer wanted to have metal in their mouths, so they asked for a material that had the same color as their teeth and that concealed the restoration at the same time. This is how more aesthetic material that fulfilled these demands was developed: composite, ceramic and ceromer (CERamic Optimized polyMER), among others.

There are two different types of restoration: the direct one, those that can be put directly into the tooth cavity in just one appointment; and the indirect restoration, which are manufactured in dental laboratories and cemented in a second session. The last ones generally require the patient to visit the dental clinic two times or more, before finishing the restoration (ADA Council on Scientific Affairs, 2003; Lanata, 2003). The use of indirect restorations have increased in tooth with great dental destruction due to their physical and mechanical properties that bestow higher durability than other type of restorations and guarantee resistance to the remaining tooth. Another advantage is that multiple laboratory stages can be done without the patient, thereby avoiding additional time spent in the dental office (ADA Council on Scientific Affairs).

The more used indirect restorations materials are composites, ceramics and ceromers. The first one, also known as compound resin, is a biphasic material whose components are represented by an organic matrix and a ceramic filling that grants the optical and

\footnotetext{
* Cirujano Dentista, Magister (c) en Gestión y Administración en Salud, Centro de Referencia e Implantológico Municipal, Concepción, Chile.

* Cirujano Dentista, Especialista en Rehabilitación Oral Avanzada e Implantología.

*** Cirujano Dentista, Diplomado (c) en Metodología de la Investigación Clínica, Facultad de Odontología, Universidad del Desarrollo, Concepción, Chile.
} 
mechanical properties needed for restoration (Lanata; Macchi, 2000). Ceramics, a material formed by nonmetallic inorganic substances, which joined with metallic oxides originates the known dental porcelain (Lanata; Macchi). Ceromers, a biphasic material formed by an organic matrix modified with polymers and a ceramic filling that grants the mechanical and optical properties (Lanata; Macchi). All these materials have excellent aesthetic results, making the restoration almost imperceptible, but like all restorative material they have their disadvantages; in this case, their limited resistance to the forces produced inside the oral cavity. One of these forces is flexion (Reis \& Borges, 2005), which can be tested using a three-point flexure test, a four-point flexure test or a biaxial flexure test. The threepoint analysis employs rectangular bar samples submitted to a central loading, creating a non-uniform stress field (Fischer et al., 2008) and producing compressive stress where the load is applied and tensile stress on the lower surface of the specimen (Della Bona et al., 2008). The resistance to flexion is reflected in the capacity of a material to endure traction efforts and therefore the risk of fracture (Enqvist et al., 2007).

The objective of the study was to assess the flexural resistance of Filtek P60, IPS e.max Press, Adoro and Ceramage in vitro, and to prove the hypothesis that ceramic has a higher flexural resistance than ceromer and composite.

\section{MATERIAL AND METHOD}

The study was an evaluation of dental materials which objective was to compare the resistance to flexion of composite Filtek P60 (3M ESPE, St. Paul, MN, U.S.); ceramic IPS e.max Press (Ivoclar Vivadent, Schaan, Liechtenstein); ceromers Adoro (Ivoclar Vivadent) and Ceramage (Shofu, San Marcos, CA, U.S).

Ten bars of composite Filtek P60, were made with measures $25 \mathrm{~mm} \times 2 \mathrm{~mm} \times 2 \mathrm{~mm}$ following the manufacturer's instructions and the 27 ANSI/ADA specifications (Council on Dental Materials and Devices, 1993). The material was compacted inside a stainless steel mold positioned between two glass slides. It was light-cured for 20 seconds with an Elipar 2500 Curing Light (3M ESPE) according to the manufacturer's instructions. Excesses were eliminated with a Sof-Lex strip (3M ESPE).
For the Adoro and Ceramage ceromers ten specimens were made for each type, with the same measures than composite and following the manufacturer's instructions and the 53 ANSI/ADA specifications (Council on Dental Materials and Devices, 2004). The same mold was used. It was light cured in a Triad $\circledast 2000$ VLC Unit (Dentsply, York, PA, USA) for 5 minutes according to the manufacturer's instructions. The excesses were eliminated with a SofLex strip.

For the IPS e.max Press ceramic, ten samples were made following the manufacturer's instructions and the 69 ANSI/ADA specifications (Council on Dental Materials and Devices, 1991). Wax patterns were made with the aforementioned measures and injected ceramic was used to make the samples. These were cooked in a dental laboratory, using a ceramics cooking oven at a temperature and time determined by the manufacturer. The samples were first polished with diamond discs of $30 \mu \mathrm{m}$ to $40 \mu \mathrm{m}$, followed by discs of $15 \mu \mathrm{m}$ to $20 \mu \mathrm{m}$.

All the samples were stored in distilled water at 37 degree Celsius for twenty-four hours and their measures were checked with a digital caliper (Digimatic caliper, Mitutoyo Corp., Tokyo, Japan). The specimens were submitted to a three-point test using the Instron machine (Instron $®$, Barcelona, España) at a crosshead speed of $1 \mathrm{~mm} / \mathrm{min}$ until fracture. The maximum breaking load of each specimen was obtained, and the flexural resistance $(\mathrm{MPa})$ was calculated using the following formula:

$$
\delta_{f}=\frac{3 F I}{2 b h^{2}}
$$

Where:

F: Maximum load in Newton

I: Distance between the supports

b: Length

h: Height

The results were statistically analyzed using an ANOVA and Scheffe test, at a significance level of $5 \%$.

\section{RESULTS}

The flexural resistance of composite Filtek P60, ceramic IPS e.max Press, and ceromers Adoro and Ceramage was tested. Ten bars of each material were 
submitted to a three-point test until fracture, to determine the resistance to flexion.

The statistical analysis pointed out significant differences between materials for the flexural strength (Table I). The average values demonstrated that Filtek P60 flexural resistance was significantly higher than Ceramage $(p<0.05)$.

An interesting finding was that ceromers values were quite dissimilar, showing differences between materials of the same type but different manufacture (Fig. 1). Also, Adoro's mean value was significantly lower than all other materials $(p<0.05)$.

Flexural strength values can be arranged from highest to lowest in the following order: Filtek P60 > IPS e. max $>$ Ceramage $>$ Adoro.

Table I. Average flexural strength (MPa) and standard deviation for each material.

\begin{tabular}{lcc}
\hline Material & $\begin{array}{c}\text { Flexural Strength } \\
\text { (MPa) }\end{array}$ & $\begin{array}{c}\text { Standard } \\
\text { Deviation }\end{array}$ \\
\hline Filtek P60 & 157,98 & 14.22 \\
Ceramage & 137,01 & 18.71 \\
Adoro & 90,25 & 6.54 \\
IPS e.max & 142,48 & 15.8 \\
\hline
\end{tabular}

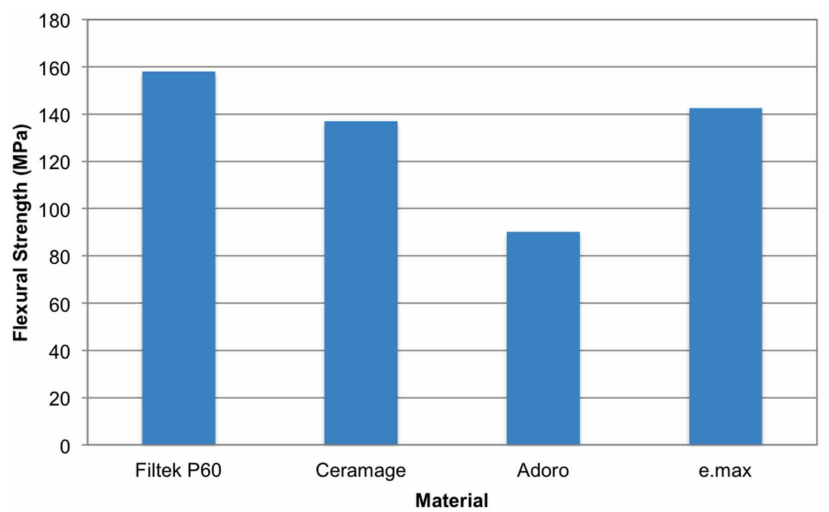

Fig. 1. Average flexural strength (MPa) of Filtek P60, Ceramage, Adoro and IPS e.max Press.

\section{DISCUSSION}

In this health technology evaluation study, the main purpose was to compare the resistance to flexion of composite Filtek P60, ceramic IPS e.max Press and ceromers Adoro and Ceramage. According to the values obtained after the test, the composite presented the highest flexural resistance, while the ceromer Adoro showed the lowest value.

The Filtek P60 is a photo-curable resin that has a particle size of $0.01 \mu \mathrm{m}$ to $3.5 \mu \mathrm{m}$ with an average of $0.6 \mu \mathrm{m}$. Its composition is basically UDMA and BisEMA, which gives special properties like less contraction to curing, a high resistance to traction and flexion; in addition its handling is much softer (Rodrigues Junior et al., 2007). Ceramage unlike other light curing resins, possess in its composition a 73\% of ceramic filing which enhances its flexural and esthetic resistance considerably, but without reaching the physical properties of Filtek P60. Adoro is compounded by nanometric particles and unaliphatic dimethacrylate of low viscosity manufactured by the same company to replace UDMA and Bis-EMA, having and easier manipulation and chromatic stability. The IPS e.max Press ceramic is compound by lithium disilicate at a $70 \%$ to be used through an injection technique, which gives very aesthetic properties and high resistance to the mechanical forces. It is necessary to make absolutely clear that the research was executed in vitro, whereby its resistances may differ than in mouth because of the cementation and the "mono-block" formation.

Through the research it was determined that Filtek P60 is significantly higher than Ceramage, and that Adoro is significantly lesser than all the other compared materials regarding flexural resistance; whereby the raised hypothesis is nullified. The results of the study can lead to new research, like testing the effect on the flexural strength of pre-heating the composite before polymerization. Additionally it is recommended to study the elastic module on the materials used in this research, to have more parameters to compare the materials with. Also a flexural resistance test of the different types of materials in teeth could be done to determine the flexural resistance in a "mono-block".

MUÑOZ, F. I.; FLORIO, M. R. \& VELÁSQUEZ, C. M. Resistencia flexural de restauraciones indirectas estéticas. Estudio comparativo in vitro. Int. J. Odontostomat., 7(2):315$318,2013$.

RESUMEN: El uso de restauraciones indirectas ha aumentado en los dientes con gran destrucción coronaria debido a sus propiedades físicas y mecánicas que confieren mayor durabilidad que otro tipo de restauraciones. El objetivo del estudio fue comparar la resistencia a la flexión de cuatro materiales de restauración indirecta (composite 
Filtek P60; cerómeros Adoro y Ceramage; cerámica IPS e.max), probando la hipótesis de que la cerámica tiene una mayor resistencia a la flexión que el cerómero y el composite. Diez barras de cada material fueron realizadas de acuerdo a las normas ANSI/ADA 27, 53 y 69 y siguiendo las instrucciones del fabricante. La resistencia a la flexión se obtuvo mediante una prueba de tres puntos utilizando una máquina Instron a una velocidad de carga de $1 \mathrm{~mm} / \mathrm{min}$. La resistencia se calculó en MPa y los resultados fueron analizados estadísticamente mediante ANOVA y una prueba de Scheffe. La resistencia a la flexión de Filtek P60 es considerablemente mayor que Ceramage. La resistencia a la flexión de Adoro es significativamente más baja que todos los otros materiales. Debe quedar absolutamente claro que la investigación fue realizada in vitro, por lo que la resistencia de los materiales podría ser diferente que en boca debido a la cementación y la formación de un "mono-bloque". A través de la investigación, se determinó que la resistencia a la flexión de Filtek P60 es significativamente superior a Ceramage, y la de Adoro es significativamente inferior a todos los demás materiales en comparación; con lo que la hipótesis planteada es anulada.

PALABRAS CLAVE: fenómenos mecánicos, restauración dental permanente, composite, cerámica, materiales dentales.

\section{REFERENCES}

ADA Council on Scientific Affairs. Direct and indirect restorative materials. J. Am. Dent. Assoc., 134(4):46372, 2003.

Council On Dental Materials And Devices. New American Dental Association Specification No 69 for dental ceramic. Chicago, American Dental Association, 1991.

Council On Dental Materials And Devices. New American Dental Association specification $N^{\circ} 27$ for direct filling resins. Chicago, American Dental Association, 1993.

Council On Dental Materials And Devices. New American Dental Association Specification N $N^{\circ} 53$ for direct Polymerbase crown and bridge materials. Chicago, American Dental Association, 2004.

Della Bona, A.; Benetti, P.; Borba, M. \& Cecchetti, D. Flexural and diametral tensile strength of composite resins. Braz. Oral Res., 22(1):84-9, 2008.

Engqvist, H.; Kraft, L.; Lindqvist, K.; Ahnfelt, N. \& Hermansson, L. Flexural strength measurement of ceramic dental restorative materials. J. Adv. Mater., 39(1):41-5, 2007.

Fischer, J.; Stawarczyk, B. \& Hämmerle, C. H. Flexural strength of veneering ceramics for zirconia. J. Dent., 36(5):316-21, 2008.

Lanata, E. Operatoria Dental. Buenos Aires, Grupo Guia, 2003.

Macchi, R. L. Materiales Dentales. $3^{\circ}$ ed. Buenos Aires, Medica Panamericana, 2000.

Reis, R. F. \& Borges, P. C. Alternative methodology for flexural strength testing in natural teeth. Braz. Dent. J., 16(1):459, 2005.

Rodrigues Junior, S. A.; Zanchi, C. H.; Carvalho, R. V. \& Demarco, F. F. Flexural strength and modulus of elasticity of different types of resin-based composites. Braz. Oral Res., 21(1):16-21, 2007.

Correspondence to:

Manuel Velásquez Castilla

Barros Arana 1735, Concepción

CHILE

Fono-Fax 56-41-2268814

Email: manuelvelasquez@udd.cl

Received: 29-01-2013

Accepted: 04-08-2013 